By declining to reach the comity question in Philipp and remanding Simon for further proceedings based on Philipp, ${ }^{52}$ the Court left in place a circuit split between the D.C. and Seventh Circuits regarding whether comity applies to claims brought under the FSIA when plaintiffs fail to exhaust local remedies. ${ }^{53}$ As a result, the Court will likely need to grant certiorari in the future to settle the question.

\title{
INTERNATIONAL Human Rights AND Humanitarian LAW
}

\section{Military Coup in Burma Draws International Condemnation and Pressure} doi:10.1017/ajil.2021.31

On February 1, 2021, the military in Burma ${ }^{1}$ overthrew the democratically elected government, declared a one-year state of emergency, and installed Senior General Min Aung Hlaing as the head of government. Since the coup, the military has cracked down on protestors, killing over 800 people and detaining many more. Numerous countries and international organizations, including the United States and the United Nations, have condemned the coup and ensuing violence and called for the restoration of a democratic government. The United States and other countries have also imposed rigorous sanctions on the Burmese military, its officials and affiliated corporations, and social media companies have imposed content restrictions to prevent the spread of pro-military propaganda.

This is not the first military coup in Burma. The Burmese military seized power in 1962 and maintained control over the country for forty-nine years. ${ }^{2}$ After elections in 2010, Burma began a peaceful transition from authoritarian rule to a quasi-civilian government, ${ }^{3}$ and in 2015, the military accepted election results that brought the National League for Democracy (NLD), led by Aung San Suu Kyi, to power. ${ }^{4}$ Even after this transition, however, the military retained significant control over key cabinet positions and national corporations. ${ }^{5}$ Burma and its military in particular have drawn international condemnation since the 2017 launch of a violent campaign against the Rohingya, a Muslim ethnic minority, that forced over 750,000 refugees to flee the country. ${ }^{6}$ Even in the face of allegations that the campaign

52 Republic of Hungary v. Simon, 141 S. Ct. at 691.

53 Fischer v. Magyar Âllamvasutak Zrt., 777 F.3d 847, 858-59 (7th Cir. 2015); Brief for the United States as Amicus Curiae Supporting Petitioners on Petition for a Writ of Certiorari at 10, Republic of Hungary v. Simon, 141 S. Ct. 691 (2021) (No. 18-1447).

${ }^{1}$ In 1989, the Burmese military government renamed the country "Myanmar," but the U.S. government continues to call the country "Burma." U.S. Dep't of State Press Release, Bilateral Relations Fact Sheet: U.S. Relations with Burma (Jan. 21, 2020), at https://www.state.gov/u-s-relations-with-burma [https://perma.cc/2ZSK-5RBV]. This Article uses "Burma" for consistency with the U.S. government naming convention.

${ }^{2}$ Hannah Beech, Myanmar's Leader, Daw Aung San Suu Kyi, Is Detained Amid Coup, N.Y. Times (Jan. 31, 2021), at https://www.nytimes.com/2021/01/31/world/asia/myanmar-coup-aung-san-suu-kyi.html.

${ }^{3}$ U.S. Dep't of State, Bilateral Relations Fact Sheet, supra note 1.

${ }^{4}$ Beech, supra note 2.

${ }^{5}$ Id.

${ }^{6}$ U.S. Dep't of State, Bilateral Relations Fact Sheet, supra note 1; see also Kristina Daugirdas \& Julian Davis Mortenson, Contemporary Practice of the United States, 112 AJIL 322 (2018). 
was genocidal, Aung San Suu Kyi and the civilian government defended the military's actions. $^{7}$

Despite this delicate alliance between the civilian government and the military, concerns about a military coup began to surface in October $2020 .^{8}$ The NLD decisively won the November 2020 election, securing 396 out of 479 Parliamentary seats; in contrast, the Union Solidarity and Development Party (USDP), the military's proxy party, won only thirty-three seats. ${ }^{9}$ The USDP refused to recognize the election results and claimed that early voting showed evidence of "widespread violation of laws and procedures." 10 Subsequent talks between the military and civilian leaders failed, ${ }^{11}$ and during the last week of January, military vehicles began appearing in at least two cities. ${ }^{12}$ On January 28, 2021, UN Secretary-General António Guterres warned against any military provocations in Burma. ${ }^{13}$ The next day, seventeen diplomatic missions in Burma, including the U.S. embassy, released a joint statement opposing "any attempt to alter the outcome of the elections or impede Myanmar's democratic transition."14

On February 1, the newly elected Parliament was supposed to be sworn in, ${ }^{15}$ but instead, the military declared a one-year state of emergency and seized control. ${ }^{16}$ By the evening of February 1, the military had formed a new cabinet, in which every minister was a former or current military general. ${ }^{17}$ After detaining civilian leaders like Aung San Suu Kyi, President U Win Myint, cabinet ministers, and opposition politicians, the Burmese military announced that ultimate authority had been transferred to the army chief, Senior General Min Aung Hlaing. ${ }^{18}$ The military justified its actions on the grounds of voter fraud in the November 2020 elections $^{19}$ and announced that it would administer new elections at the end of the one-year state of emergency. ${ }^{20}$ Aung San Suu Kyi and deposed president U Win Myint were charged with obscure criminal violations that could result prison sentences. ${ }^{21}$

${ }^{7}$ Beech, supra note 2 .

${ }^{8} \mathrm{Id}$.

${ }^{9} I d$.

${ }^{10}$ Myanmar: Aung San Suu Kyi's Party Wins Majority in Election, BBC (Nov. 13, 2020), at https://www.bbc. $\mathrm{com} /$ news/world-asia-54899170.

${ }^{11}$ Beech, supra note 2 .

${ }^{12} \mathrm{Id}$.

${ }^{13}$ Id.; UN Secretary-General, Statement Attributable to the Spokesperson for the Secretary-General - on Myanmar (Jan. 28, 2021), at https://www.un.org/sg/en/content/sg/statement/2021-01-28/statement-attributable-the-spokesperson-for-the-secretary-general-myanmar.

${ }^{14}$ Australia, Canada, the European Union, Denmark, Czech Republic, Finland, France, Germany, Italy, Netherlands, New Zealand, Norway, Spain, Sweden, Switzerland, the United Kingdom, and the United States signed the joint statement. Id.; U.S. Embassy in Burma, Joint Statement by Diplomatic Missions in Myanmar (Jan. 29, 2021), at https://mm.usembassy.gov/joint-statement-by-diplomatic-missions-in-myanmar [https:// perma.cc/SH3A-4QZP].

${ }^{15}$ See U.S. Dep't of Treasury Press Release, United States Targets Leaders of Burma's Military Coup Under New Executive Order (Feb. 11, 2021), at https://home.treasury.gov/news/press-releases/jy0024.

${ }^{16} I d$.

${ }^{17}$ Hannah Beech, Myanmar's Army Is Back in Charge. It Never Truly Left, N.Y. Times (Feb. 2, 2021), at https:// www.nytimes.com/2021/02/02/world/asia/myanmar-military-coup.html.

${ }^{18}$ Beech, supra note 2.

${ }^{19} \mathrm{Id}$.

${ }^{20} I d$.

${ }^{21}$ Hannah Beech, Trial for Aung San Suu Kyi Begins in Secret, N.Y. TIMEs (Feb. 16, 2021), at https://www. nytimes.com/2021/02/16/world/asia/myanmar-trial-aung-san-suu-kyi.html. 
The military quickly seized control of telecommunications on February 1, suspending telephone and internet access in major cities; cancelling flights; and shutting down the stock market and banks. ${ }^{22}$ The following week, the military junta circulated a draft cybersecurity law to telecommunications and internet companies, purporting to allow the military to block websites and cut off access to "troublesome" users and to allow the government to access users' data. ${ }^{23}$ On March 8, state television announced that the military had revoked the licenses of five independent media organizations. ${ }^{24}$

Protests began immediately following the coup and grew in size as the military escalated its response against protestors. ${ }^{25}$ The number of protesters dramatically increased on February 22, when millions of workers joined a mass Civil Disobedience Movement (CDM); the movement has adversely affected many sectors of the country's economy, including causing up to ninety percent of national government activity to cease. ${ }^{26}$ Some protestors began calling on foreign countries to invade Burma, with the hashtag \#R2P (short for "responsibility to protect") trending on Twitter in Burma. ${ }^{27}$ In mid-February, the military began using lethal force against protestors, and it has continued to escalate its use of force in subsequent months. ${ }^{28}$ As of late June, the military had killed more than 800 and detained more than 5,000 people according to the Assistance Association for Political Prisoners. ${ }^{29}$ At least forty of the dead are children. ${ }^{30}$ According to the UN high commissioner for human rights, hundreds of detainees have disappeared, at least five have died while in custody, and at least two have been tortured. ${ }^{31}$

The United States, its allies, and the United Nations have sought to provide a coordinated response to the coup. On February 1, President Biden released a statement declaring the coup a "direct assault on the country's transition to democracy and the rule of law." 32 Biden called on the international community to work together to pressure the Burmese military to change course, stating:

\footnotetext{
${ }^{22}$ Russell Goldman, Myanmar's Coup and Violence, Explained, N.Y. Times (Apr. 12, 2021), at https://www. nytimes.com/article/myanmar-news-protests-coup.html.

${ }^{23}$ Hannah Beech \& Paul Mozur, A Digital Firewall in Myanmar, Built with Guns and Wire Cutters, N.Y. TIMES (Feb. 23, 2021), at https://www.nytimes.com/2021/02/23/world/asia/myanmar-coup-firewall-internet-china. html.

${ }^{24}$ Hannah Beech, Myanmar Military Storms Universities and Hospitals and Revokes Press Licenses, N.Y. TIMES (Mar. 8, 2021), at https://www.nytimes.com/2021/03/08/world/asia/myanmar-coup-violence.html.

${ }^{25}$ Goldman, supra note 22.

${ }^{26}$ Hannah Beech, Myanmar Protesters Answer Military's Bullets With an Economic Shutdown, N.Y. Times (Mar. 19, 2021), at https://www.nytimes.com/2021/03/19/world/asia/myanmar-workers-strike.html; Goldman, supra note 22 .

27 Beech, supra note 24 .

${ }^{28}$ Goldman, supra note 22.

${ }^{29}$ Assistance Association for Political Prisoners, at https://aappb.org.

${ }^{30}$ Tommy Beer, At Least 43 Children Killed By Myanmar Military Forces, Humanitarian Group Reports, FORBES (Apr. 1, 2021), at https://www.forbes.com/sites/tommybeer/2021/04/01/at-least-43-children-killed-by-myanmar-military-forces-humanitarian-group-reports/?sh=7133f3642e71.

${ }^{31}$ Richard C. Paddock, Beaten, Cuffed, Hauled Away: When Myanmar's Military Comes Knocking, N.Y. TIMES (Mar. 26, 2021), at https://www.nytimes.com/2021/03/26/world/asia/myanmar-military-protesters-arrests. html.

32 Joseph R. Biden, Jr., Statement on the Situation in Burma, 2021 Daily Comp. Pres. Doc. 105, at 1 (Feb. 1, 2021).
} 
The international community should come together in one voice to press the Burmese military to immediately relinquish the power they have seized, release the activists and officials they have detained, lift all telecommunications restrictions, and refrain from violence against civilians. The United States is taking note of those who stand with the people of Burma in this difficult hour. We will work with our partners throughout the region and the world to support the restoration of democracy and the rule of law, as well as to hold accountable those responsible for overturning Burma's democratic transition. ${ }^{33}$

On February 4, the UN Security Council released a statement sounding similar notes, calling for the immediate release of detained officials, including Aung San Suu Kyi, and emphasizing its support for continued democratic transition. ${ }^{34}$

On February 14, the Burmese military intensified its crackdown on protestors by moving military units into cities, trying to disperse crowds with force, surrounding houses of protesting government employees, and threatening to shoot protestors. ${ }^{35}$ In response to this crackdown, a group of fifteen ambassadors to Burma, including the U.S. ambassador, released a statement stating:

We call on security forces to refrain from violence against demonstrators and civilians, who are protesting the overthrow of their legitimate government.

We unequivocally condemn the detention and ongoing arrests of political leaders, civil society activists, and civil servants, as well as the harassment of journalists.

We also denounce the military's interruption of communications, as well as the restriction of the Myanmar people's fundamental rights and basic legal protections.

We support the people of Myanmar in their quest for democracy, freedom, peace, and prosperity. The world is watching. ${ }^{36}$

On February 23, the G7 foreign ministers also released a statement warning, among other things, that "[u]se of live ammunition against unarmed people is unacceptable" and that "[a]nyone responding to peaceful protests with violence must be held to account." 37

The Biden administration's primary response to the coup has been the imposition of a series of sanctions, sometimes in conjunction with European allies, against Burmese military officials and companies they control. On February 10, President Biden announced that he

${ }^{33} \mathrm{Id}$.

${ }^{34}$ UN Press Release, Security Council Press Statement on Situation in Myanmar (Feb. 4, 2021), at https:// www.un.org/press/en/2021/sc14430.doc.htm [https://perma.cc/ZSJ4-WJNC].

${ }^{35}$ Hannah Beech, Military Imposes Full Grip on Myanmar in Overnight Crackdown, N.Y. Times (Feb. 14, 2021), at https://www.nytimes.com/2021/02/14/world/asia/myanmar-military-crackdown.html; Paddock, supra note 31 .

${ }^{36}$ Canada, the European Union Delegation, Denmark, Czech Republic, Finland, France, Germany, Italy, Netherlands, Norway, Spain, Sweden, Switzerland, the United Kingdom, and the United States signed the statement initially; Australia and New Zealand later joined the statement. U.S. Embassy in Burma Press Release, Statement by Ambassadors to Myanmar, at https://mm.usembassy.gov/statement-by-ambassadors-to-myanmar [https://perma.cc/GVQ2-W9L8].

37 U.S. Dep't of State Press Release, G7 Foreign Ministers' Statement on Burma (Feb. 23, 2021), at https:// www.state.gov/g7-foreign-ministers-statement-on-burma [https://perma.cc/6SB4-NTMU]. 
would impose sanctions to prevent access to one billion dollars in Burmese government funds kept in the United States. ${ }^{38}$ The next day, the administration announced a series of actions by multiple agencies to pressure the Burmese military. ${ }^{39}$ President Biden issued an executive order that declared a national emergency to address the threat posed by the coup in Burma. ${ }^{40}$ Citing the Constitution, the International Emergency Economic Powers Act, the National Emergencies Act, and the Immigration and Nationality Act, the order authorizes sanctions to block the property and prevent entry into the United States of military leaders and anyone involved in the coup, violence against protestors, or suppression of free speech. ${ }^{41}$ The order also permits sanctions against the spouses and adult children of such persons. ${ }^{42}$ Pursuant to the order, the U.S. Treasury Department designated ten individuals who played a leading role in the coup and three entities affiliated with the military. ${ }^{43}$ In addition, the Commerce Department restricted exports of sensitive items to Burma's military and security services. ${ }^{44}$ The U.S. Agency for International Development (USAID) also redirected $\$ 42.4$ million away from projects benefiting the Burmese government, while maintaining \$69 million in funding for programs with direct benefits to the Burmese population. ${ }^{45}$ On March 4 , the Commerce Department implemented new export controls against Burma and added four entities associated with the coup to the Entity List, arguing that "[w]e will not allow the Burmese military to continue to benefit from access to items subject to the [Export Administration Regulations]." 46

On March 8, the Burmese military further solidified its control by taking over hospitals, universities, and Buddhist complexes and escalated its use of force against protestors, fatally shooting protestors and trapping hundreds in a security force cordon. ${ }^{47}$ In response to the violence, the UN Security Council president issued a statement that "strongly condemn[ed] the violence against peaceful protestors, including against women, youth and children," and expressed support for efforts by the Association of Southeast Asian Nations (ASEAN) to

38 David E. Sanger, Biden Imposes Sanctions on Generals Who Engineered Myanmar Coup, N.Y. Times (Feb. 10, 2021), at https://www.nytimes.com/2021/02/10/us/politics/biden-sanctions-myanmar-coup.html. Even prior to this announcement, the Federal Reserve Bank of New York blocked an attempt by the Burmese military to move the funds. Simon Lewis \& Humeyra Pamuk, Exclusive: U.S. Blocked Myanmar Junta Attempt to Empty \$1 Billion New York Fed Account - Sources, ReuTERs (Mar. 4, 2021), at https://www.reuters.com/article/us-myanmar-politics-usa-fed-exclusive-idUSKCN2AW2MD.

${ }^{39}$ White House Press Release, Fact Sheet: Biden-Harris Administration Actions in Response to the Coup in Burma, at https:/www.whitehouse.gov/briefing-room/statements-releases/2021/02/11/fact-sheet-biden-harrisadministration-actions-in-response-to-the-coup-in-burma [https://perma.cc/6JXP-GW2T].

${ }^{40}$ Exec. Order 14,014, 86 Fed. Reg. 9429, 9429-430 (Feb. 12, 2021).

${ }^{41} I d$.

${ }^{42} I d$.

43 U.S. Dep't of Treasury Press Release, supra note 15.

${ }^{44}$ U.S. Dep't of Commerce Press Release, U.S. Commerce Department Restricts Licensing of Sensitive Exports to Burma's Military and Security Services in Response to the Recent Military Coup (Feb. 11, 2021), at https://www. commerce.gov/news/press-releases/2021/02/us-commerce-department-restricts-licensing-sensitive-exports-burmas.

${ }^{45}$ USAID Press Release, USAID Immediately Redirects \$42 Million in Response to the Military Coup in Burma (Feb. 11, 2021), at https://www.usaid.gov/news-information/press-releases/feb-11-2021-usaid-immediatelyredirects-42-million-response-military-coup-burma.

${ }^{46}$ U.S. Dep't of Commerce Press Release, Commerce Implements New Export Controls on Burma and Makes Entity List Additions in Response to the Military Coup and Escalating Violence Against Peaceful Protesters (Mar. 4, 2021), at https:/www.commerce.gov/news/press-releases/2021/03/commerce-implements-new-exportcontrols-burma-and-makes-entity-list.

${ }^{47}$ Beech, supra note 24. 
engage with the relevant parties in Burma. ${ }^{48}$ The United States also responded with sanctions against two adult children of Min Aung Hlaing and six entities owned or controlled by these individuals pursuant to Executive Order 14,014. ${ }^{49}$ In announcing Treasury's designations, Secretary of State Antony Blinken noted that the designations are intended "to respond to the violence enabled by Burma's military leaders, to promote accountability for those responsible for the coup, and to target those who benefit financially from their connections to the military regime." ${ }^{50} \mathrm{He}$ added, "The leaders of the coup, and their adult family members, should not be able to continue to derive benefits from the regime as it resorts to violence and tightens its stranglehold on democracy." 51 Additional sanctions have followed, including in coordination with the European Union, ${ }^{52}$ and the United States has taken steps to limit travel to Burma and provide Temporary Protected Status for Burmese refugees for eighteen months. ${ }^{53}$

As the casualties have risen in Burma, Congress has pushed for stronger responses. On March 18, the U.S. House of Representatives passed a bill that would require the Biden administration to provide a report to Congress on the coup and the administration's responses to it. ${ }^{54}$ On March 19, the House passed a resolution condemning the coup and calling on the Biden administration to take additional actions, including imposing multilateral sanctions on military-owned businesses, ensuring that U.S.-based social media companies prevent Burmese military-sponsored disinformation campaigns, and restricting relations with Burma until the restoration of a civilian government. ${ }^{55}$

On March 23, military forces fatally shot a seven-year-old girl as they fired randomly into homes. ${ }^{56}$ On March 25, the State Department condemned the Burmese military's continued use of lethal force against civilians, particularly against children. ${ }^{57}$ The statement said, in part:

${ }^{48}$ U.S. Embassy in Burma Press Release, Statement by the President of the Security Council on Myanmar, March 10, 2021 (Mar. 10, 2021), at https://mm.usembassy.gov/statement-by-the-president-of-the-securitycouncil-on-myanmar-march-10-2021 [https://perma.cc/55N4-TAP2].

${ }^{49}$ U.S. Dep't of Treasury Press Release, United States Targets Family Members Profiting from Connection to Burmese Coup Leader (Mar. 10, 2021), at https://home.treasury.gov/news/press-releases/jy0051.

${ }^{50}$ U.S. Dep't of State Press Release, Promoting Accountability and Responding to Violence Against Protestors in Burma (Mar. 10, 2021), at https:/www.state.gov/promoting-accountability-and-responding-to-violenceagainst-protestors-in-burma [https://perma.cc/ZW5R-TSVV].

${ }^{51} I d$.

${ }^{52}$ U.S. Dep't of State Press Release, Designating Officials and Military Units in Response to Escalating Violence in Burma (Mar. 22, 2021), at https://www.state.gov/designating-officials-and-military-units-inresponse-to-escalating-violence-in-burma [https://perma.cc/M7UF-SVV3].

${ }^{53}$ U.S. Dep't of State, Burma (Myanmar) Travel Advisory (Mar. 30, 2021), at https://travel.state.gov/content/ travel/en/traveladvisories/traveladvisories/burma-travel-advisory.html [https://perma.cc/RXB7-GUZL]; U.S. Dep't of Homeland Security Press Release, Secretary Mayorkas Designates Burma for Temporary Protected Status (Mar. 12, 2021), at https://www.dhs.gov/news/2021/03/12/secretary-mayorkas-designates-burma-temporary-protected-status [https://perma.cc/3AJ4-9NXZ]

${ }^{54}$ Reuters Staff, U.S. House Backs Measure Condemning Myanmar Coup, ReuTers (Mar. 19, 2021), at https:// www.reuters.com/article/us-myanmar-politics-usa-congress/u-s-house-backs-measure-condemning-myanmarcoup-idUSKBN2BB23K.

${ }^{55}$ H. Res. 134, 117th Cong. (2021).

${ }^{56}$ Hannah Beech, "I Will Die Protecting My Country": In Myanmar, a New Resistance Rises, N.Y. Times (Mar. 24, 2021), at https://www.nytimes.com/2021/03/24/world/asia/myanmar-coup-resistance-protests.html.

57 U.S. Dep't of State Press Release, The United States Strongly Condemns the Recent Killing of People in Burma, Including Children, by the Burmese Military (Mar. 25, 2021), at https://www.state.gov/the-unitedstates-strongly-condemns-the-recent-killing-of-people-in-burma-including-children-by-the-burmese-military [https://perma.cc/9CPU-AD29]. 
These abhorrent and brutal acts against children, one as young as seven years old who was shot and killed in her home while sitting on her father's lap, further demonstrate the horrific nature of the Burmese military regime's assault on its own people and its complete disregard for the lives of the people of Burma." 58

That same day, the United States and United Kingdom sanctioned Burmese corporations controlled by the military. ${ }^{59}$

Following the March 25 U.S. and UK actions, chairman of the Senate Foreign Relations Committee's East Asia Subcommittee, Senator Ed Markey, expressed support for the sanctions but called for further action "to deny the army its economic lifeline and to deny it the weapons of war," arguing that "[t]he United States should play a leading role in urging our partners and allies, including members of ASEAN, to take steps to cut off funding for the military." ${ }^{00}$ Human Rights Watch also called the March 25 sanctions "a very important step" but tempered its praise by noting "it is not the biggest economic sanction that could be implemented." 11 Internationally, UN Special Envoy for Myanmar Christine Schraner Burgener warned the UN Security Council on March 31 that it should consider further action if it wanted to avoid an "imminent bloodbath" and "multi-dimensional catastrophe in the heart of Asia." 62

The United States has continued to ratchet up its response to violence by the Burmese military. March 27 saw the most violence against protestors since the coup began, with over one hundred people estimated dead, including children. ${ }^{63}$ In response, the Biden administration announced on March 29 that it would suspend all diplomatic trade engagement under the 2013 Trade and Investment Framework Agreement with Burma "until the return of a democratically elected government." 64 On April 21, the United States announced sanctions on two new military-controlled companies-two days after the European Union announced its own sanctions against ten military leaders and other military-controlled companies. ${ }^{65}$

The United States has joined other G7 members in endorsing efforts by the Association of Southeast Asian Nations (ASEAN) to address the coup following an ASEAN leaders' summit at the end of April that Senior General Min Aung Hlain attended on behalf of Burma. ${ }^{66}$ In a

\footnotetext{
${ }^{58} \mathrm{Id}$.

${ }^{59}$ Reuters Staff, U.S. and Britain Blacklist Myanmar Military-Controlled Companies, ReuTERs (Mar. 25, 2021), at https://www.reuters.com/article/us-myanmar-politics-usa-sanctions-idUSKBN2BH1VM.

${ }^{60} \mathrm{Id}$.

${ }^{61} I d$.

${ }^{62}$ Lexi Lonas, UN Envoy Warns of "Imminent" Bloodbath in Myanmar, THE Hill (Apr. 1, 2021), at https:// thehill.com/policy/international/545937-un-envoy-warns-of-imminent-bloodbath-in-myanmar?rl=1.

${ }^{63}$ Richard C. Paddock, Dozens Are Gunned Down in “Day of Shame” for Myanmar, N.Y. Times (Mar. 27, 2021), at https://www.nytimes.com/2021/03/27/world/asia/myanmar-protests.html.

${ }^{64}$ Betsy Klein, U.S. Suspends All Diplomatic Trade Engagement with Myanmar After Weekend of Violence Against Pro-democracy Protestors, CNN (Mar. 29, 2021), at https://www.cnn.com/2021/03/29/politics/us-trade-suspension-myanmar/index.html.

${ }^{65}$ Glenn Thrush, U.S. Imposes Additional Sanctions on Myanmar, Targeting Two Companies Linked to the Country's Military, N.Y. Times (Apr. 21, 2021), at https://www.nytimes.com/2021/04/21/us/myanmar-sanctions.html; U.S. Dep't of Treasury Press Release, Treasury Sanctions Key Timber and Pearl Enterprises in Burma (Apr. 21, 2021), at https://home.treasury.gov/news/press-releases/jy0138.

66 See Richard C. Paddock, General Who Led Myanmar's Coup Joins Regional Talks on the Crisis, N.Y. TIMES (Apr. 24, 2021), at https://www.nytimes.com/2021/04/24/world/asia/myanmar-asean-general-indonesia.html;
} 
May 7 communiqué, the G7 foreign and development ministers "call[ed] on the military to restore Myanmar to the path to democracy," "committed to constructively supporting ASEAN's efforts," and pledged additional actions, including continued bans on the sale or trade of military equipment, "if the military does not reverse its course." 67 Acting with the United Kingdom and Canada, the United States subsequently imposed additional sanctions on the military regime, officials, and officials' adult children, ${ }^{68}$ while also announcing $\$ 155$ million in new funding to assist Rohingya refugees in Burma and Bangladesh. ${ }^{69}$ The State Department noted that "the coup leaders are many of the same individuals responsible for previous human rights abuses, including atrocities against Rohingya." 70

Some Burmese officials around the world have criticized the coup. On February 26, Burma's UN envoy, U Kyaw Moe Tun, denounced the coup as illegitimate in a speech to the UN General Assembly, ${ }^{71}$ prompting the Burmese military to fire him and accuse him of high treason. ${ }^{72}$ However, he refused to step down, and the UN refused to recognize his dismissal. ${ }^{73}$ Burma's ambassador to the United Kingdom, Kyaw Zwar Minn, was recalled from his post and locked out of Burma's embassy in London after issuing a statement calling for the release of Aung San Suu Kyi and President Win Myint. ${ }^{74}$ Furthermore, on April 16, former members of Burma's parliament, leaders of anti-coup protests, and leaders of ethnic minorities coalesced to form the National Unity Government, claiming they "are the democratically elected leaders of Myanmar."75

A number of countries, however, have failed to expressly condemn the coup or even expressed support for the Burmese military. On March 27, Russia's deputy defense minister, Alexander Fomin, attended the Burmese Armed Forces Day ceremony, where he received a medal and a ceremonial sword. ${ }^{76}$ A Chinese representative also attended the ceremony, and China has yet to take any definitive action against the coup, which Chinese state news agency

U.S. Dep't of State Press Release, Designating One Entity and 16 Individuals Connected to Burma's Military Regime (May 17, 2021), at https://www.state.gov/designating-one-entity-and-16-individuals-connected-to-burmas-military-regime [https://perma.cc/F9SA-57JA].

${ }^{67}$ G7 Foreign and Development Ministers' Meeting: Communiqué (May 5, 2021), at https://eeas.europa.eu/ headquarters/headquarters-homepage/97842/g7-foreign-and-development-ministers $\%$ E2\%80\%99-meetingcommuniqu\%C3\%A9_en [https://perma.cc/82Z4-4C45].

${ }^{68}$ U.S. Dep't of State Press Release, supra note 66.

${ }^{69}$ U.S. Dept' of State Press Release, The United States Announces New Assistance to Respond to the Rohingya Humanitarian Crisis (May 18, 2021), at https://www.state.gov/the-united-states-announces-new-assistance-torespond-to-the-rohingya-humanitarian-crisis [https://perma.cc/A2K4-VHKV].

${ }^{70} \mathrm{Id}$.

${ }^{71}$ Hannah Beech, After Coup in Myanmar, a Career Diplomat Takes a Stand, N.Y. Times (Mar. 6, 2021), at https://www.nytimes.com/2021/03/06/world/asia/myanmar-protests-un-ambassador.html.

${ }^{72} \mathrm{Id}$.

${ }^{73} \mathrm{Id}$.

${ }^{74}$ Stephen Castle, Myanmar Envoy Who Critiqued Coup Is Locked Out of London Embassy, N.Y. TimEs (Apr. 7 2021), at https:/www.nytimes.com/2021/04/07/world/europe/myanmar-ambassador-coup-london-embassy. html; see also Thet Htar Mya Yee San, Opinion: I'm a Myanmar Diplomat. Here's Why I Refuse to Recognize the Coup, Wash. POST (Apr. 28, 2021), at https://www.washingtonpost.com/opinions/2021/04/28/im-myanmardiplomat-heres-why-i-refuse-recognize-coup.

${ }^{75}$ Reuters Staff, Opponents of Myanmar Coup Form Unity Government, Aim for "Federal Democracy, "REUTERS (Apr. 16, 2021), at https://www.reuters.com/world/asia-pacific/opponents-myanmar-coup-announce-unity-government-2021-04-16.

${ }^{76}$ Paddock, supra note 63 
Xinhua referred to as a "major cabinet reshuffle." 77 While China has historically been supportive of the Burmese military, President Xi Jinping had also fostered a close political relationship with Aung San Suu Kyi's government, including through purchasing \$90 million in oil and gas per month, signing agreements for railroad and port projects in Burma, and encouraging Huawei's plan to establish a $5 \mathrm{G}$ cellphone network in Burma. ${ }^{78}$ China's ambassador to the United Nations, Zhang Jun, stated in May that "China supports all political parties and factions of Myanmar in seeking a political solution to their differences through dialogue within the constitutional and legal framework and continuing to advance democratic transition," and warned that "[o]ne-sided pressuring and pushing for sanctions and other coercive measures will only aggravate tensions and confrontation." ${ }^{\prime 99}$ Some observers, including former U.S. Ambassador to Myanmar Derek Mitchell, believe that the Chinese government sees the coup as "a moment of opportunity" to counter U.S. influence in the region. ${ }^{80}$

In addition to the governmental and intergovernmental responses to the coup, social media companies have taken measures to block the Burmese military from their platforms. The Burmese military has historically been prolific on Facebook, planting anti-democracy conspiracy theories in groups visited by soldiers and using the platform to incite citizens against the Rohingya minority. ${ }^{81}$ One of the first statements following the coup by General Min Aung Hlaing was posted on the Burmese military's official Facebook page. ${ }^{82}$ On February 24, Facebook announced it had blocked Burma's military from using and banned militaryowned businesses from advertising on Facebook. ${ }^{83}$ Facebook justified its decision by stating, "[e]vents since the Feb. 1 coup, including deadly violence, have precipitated a need for this ban" and cited the Burmese military's history of human rights abuses and social media manipulation. ${ }^{84}$ The ban does not, however, affect personal accounts of military officers or private groups for soldiers. ${ }^{85}$ After Facebook's ban, TikTok saw a rise in the number of Burmese soldiers and police posting threatening or pro-military videos. ${ }^{86}$ In response, TikTok released a statement that said, "[a]s it relates to Myanmar, we have been and continue to promptly remove all content that incites violence or spreads misinformation, and are aggressively monitoring to

77 Id.; see also Steven Lee Myers \& Hannah Beech, In Geopolitical Struggle Over Myanmar, China Has an Edge, N.Y. Times (Feb. 5, 2021), at https:/www.nytimes.com/2021/02/05/world/asia/myanmar-coup-china-unitedstates.html.

${ }^{78}$ Myers \& Beech, supra note 77; see Beech, supra note 26; see also David E. Sanger, Declaring Democracy Won't Be Subverted, Biden Demands Russia and Myanmar Reverse Course, N.Y. Times (Feb. 3, 2021), at https://www. nytimes.com/2021/02/03/us/politics/biden-myanmar-russia.html.

${ }^{79}$ Min. of For. Aff. of the People's Republic of China Press Release, Ambassador Zhang Jun Briefs UN Member States and the Media on the Security Council's Work for the Month of May (May 3, 2021), https://www.fmprc. gov.cn/mfa_eng/wjb_663304/zwjg_665342/zwbd_665378/t1873289.shtml [https://perma.cc/WA8S-AFLP].

${ }^{80}$ Myers \& Beech, supra note 77.

${ }^{81}$ Hannah Beech, Inside Myanmar's Army: “They See Protestors as Criminals, N.Y. Times (Mar. 28, 2021), at https://www.nytimes.com/2021/03/28/world/asia/myanmar-army-protests.html; Paul Mozur, Mike Isaac, David E. Sanger \& Richard C. Paddock, Facebook Takes a Side, Barring Myanmar Military After Coup, N.Y. Times (Feb. 24, 2021), at https://www.nytimes.com/2021/02/24/technology/facebook-myanmar-ban.html.

${ }^{82}$ Mozur, Isaac, Sanger \& Paddock, supra note 81.

${ }^{83} \mathrm{Id}$.

${ }^{84} \mathrm{Id}$.

${ }^{85} \mathrm{Id}$.

${ }^{86}$ Reuters Staff, "I Will Shoot Whoever I See": Myanmar Soldiers Use TikTok to Threaten Protesters, REUTERS (Mar. 4, 2021), at https://www.reuters.com/article/us-myanmar-tiktok/i-will-shoot-whoever-i-see-myanmar-soldiers-use-tiktok-to-threaten-protesters-idUSKBN2AW17X. 
remove any such content that violates our guidelines." 87 On March 5, YouTube announced it had removed five channels run by the Burmese military and their affiliated videos. ${ }^{88}$

Despite increasing pressure from much of the international community, including the overwhelming passage of a UN General Assembly Resolution condemning the coup, Burma's military appears unwilling to reverse course. ${ }^{89}$

\section{Use of Force, Arms Control, and Nonproliferation}

Biden Administration Relies on Constitutional Authority and Unwilling or Unable Theory of Self-Defense for Airstrikes in Syria

doi:10.1017/ajil.2021.32

On February 25, 2021, the United States conducted a strike targeting Iranian-backed militia group facilities in Syria. The strike, which came in response to a February 15, 2021 attack on U.S. interests in Iraq, marked the Biden administration's first known exercise of executive war powers. As domestic authority for the strike, President Joseph Biden, Jr. cited his authority under Article II of the U.S. Constitution and did not rely on the 2001 or 2002 Authorizations for the Use of Military Force (AUMFs). For international legal authority, Biden relied on individual self-defense under Article 51 of the UN Charter, stating that Syria was "unwilling or unable" to prevent further attacks on the United States by these non-state actors within its territory. The strikes garnered mixed reactions from Congress, where efforts are underway to repeal or reform extant AUMFs as well as the War Powers Resolution (WPR). The Biden administration is also undertaking a review of current U.S. military policy on the use of force, and during this process, it has prohibited drone strikes outside of conventional battlefields, absent presidential approval.

Violence attributed to the activities of Iranian-backed militia groups in Iraq has long been a source of tension between the United States and Iran. ${ }^{1}$ The U.S. strike that killed Iranian Quds Force Commander Qassem Soleimani while he was visiting Iraq in January 2020 marked a high point of tensions. ${ }^{2}$ In January and February 2021, as the Biden administration prepared to reopen negotiations on the Joint Comprehensive Plan of Action (JCPOA) concerning Iran's nuclear program, Iranian-backed militia groups again increased rocket attacks on U.S. assets in Iraq. ${ }^{3}$ A February 15, 2021 militia group rocket attack in Erbil,

$$
{ }^{87} I d \text {. }
$$

${ }^{88}$ Paul Mozur, YouTube Bans Myanmar Military Channels as Violence Rises, N.Y. TIMES (Mar. 5, 2021), at https://www.nytimes.com/2021/03/05/business/youtube-myanmar.html.

${ }^{89}$ Adam Taylor \& Sammy Westfall, U.N. Adopts Resolution Condemning Myanmar's Military Junta, WAsH. POsт (June 18, 2021), at https://www.washingtonpost.com/world/2021/06/18/un-set-adopt-resolution-condemning-myanmars-military-junta.

${ }^{1}$ See Jean Galbraith, Contemporary Practice of the United States, 114 AJIL 288, 313 (2020).

${ }^{2}$ For background on the legal issues surrounding the Soleimani strike, see id.

${ }^{3}$ Missy Ryan \& Mustafa Salim, Militia Strike Constitutes Key Test of Biden's Plan to Engage, Restrain Iran, WASH. Post (Feb. 26, 2021), at https://www.washingtonpost.com/national-security/us-attack-iran-militias-syria/2021/ 02/26/13227e0a-7841-11eb-ae66-8b9e3c6918a1_story.html. For additional information on the U.S. 